石油技術協会誌 第 72 巻 第 6 号 (平成 19 年 11 月)

JOURNAL OF THE JAPANESE ASSOCIATION FOR PETROLEUM TECHNOLOGY

VOL. 72 , NO. 6 (Nov., 2007)

報告

地質・生産デー夕を用いた JHN 陸豊 13-1 油田第 6 次・ 7 次掘削

キャンペーン成果と知見*

一生産後期油田における油増産の取り組み例として一

吉田 宏生 ${ }^{* *} \cdot$ 茂木 慎吾 ${ }^{* * *} \cdot$ 中川 和則 ${ }^{* * *} \cdot$ 山足 友浩 ${ }^{* *}$

(Received September 10, 2007 ; accepted November 9, 2007)

\title{
Result and knowledge of the 6th and 7th drilling campaigns based on the integrated geological and reservoir studies in Lufeng 13-1 Oil Field in South China Sea \\ - As an example of efforts for enhancement of production in late stage of the oil field-
}

\author{
Kosei Yoshida, Shingo Mogi, Kazunori Nakagawa and Tomohiro Yamaashi
}

\begin{abstract}
Lufeng 13-1 Oil Field operated by JHN Oil Operating Company (JHN) is located in South China Sea. For enhancement of oil production rate, the $6^{\text {th }}$ and $7^{\text {th }}$ drilling campaigns were carried out from 2004 to 2006 on the basis of the geological and reservoir study. Ten horizontal wells were drilled in total on these campaigns. The wells on the 6th drilling campaign show rapid decrease of oil production rate with rapid increase of water cut after production start (categorized as Type 1). On the other hand, most of the wells on the $7^{\text {th }}$ drilling campaign perform gradual decrease of oil production rate with gradual increase of water cut (categorized as Type 2) or stable oil production rate with much lower and stable water cut (categorized as Type 3). These types seem to be controlled by geological factors; permeability of the oil reservoir, presence of the low permeable zone such as mudstone or muddy sandstone just below the oil reservoir etc. The wells of Type 2 and Type 3 contribute to enhance oil production rate of the oil field significantly. The present oil production rate on the 7 th drilling campaign accounts for nearly $50 \%$ of the total oil production rate in the oil field.

Two important knowledge concerning control factors of water cut and oil production rate in late development stage of the oil field are derived from the result of the $6^{\text {th }}$ and $7^{\text {th }}$ drilling campaigns.

(1) Careful considerations of the presence of the low permeable zone acting as "barrier" or "filter" below the reservoir are needed as well as the oil reservoir quality in the target section

(2) Precise skills of reservoir navigation are required to secure enough oil reservoir section contributing in stable oil production as planned.
\end{abstract}

Key words : water cut, oil production rate, low permeable zone, water coning, barrier, filter, reservoir navigation, late stage

* 平成 19 年 6 月 6 日, 平成 19 年度石油技術協会春季講演会 開発・生産部門シンポジウム「油ガス層評価のためのデー 夕の最大活用」で講演 This paper was presented at the 2007 JAPT Development and Production Technology Symposium entitled "Full utilization of various data for better reservoir evaluation" held in Yoyogi, Tokyo, Japan, June 6, 2007.

** 石油資源開発(制探鉱本部 Japan Petroleum Exploration Co., Ltd., Exploration Division

炏* 石油資源開発株)開発本部 Japan Petroleum Exploration Co., Ltd., Development Divisio

Copyright (C) 2007, JAPT

\section{1. はじめに}

陸豊（ルーフェン, LF と略称）13-1 油田は, 香港か ら東南東の沖合約 $250 \mathrm{~km}$ の南シナ海に位置する油田で ある（図 1）。本油田は, 1986 年, JHN 石油作業公司（新 南海石油開発(侏), 新華南石油開発(侏), 日鉱珠江口石油 開発(制の共同操業会社）によって発見された。本油田 は生産開始から 13 年あまりがたち, 既存生産井からの 生産量減退が進行し, 平均水含有量は総生産流体中の 


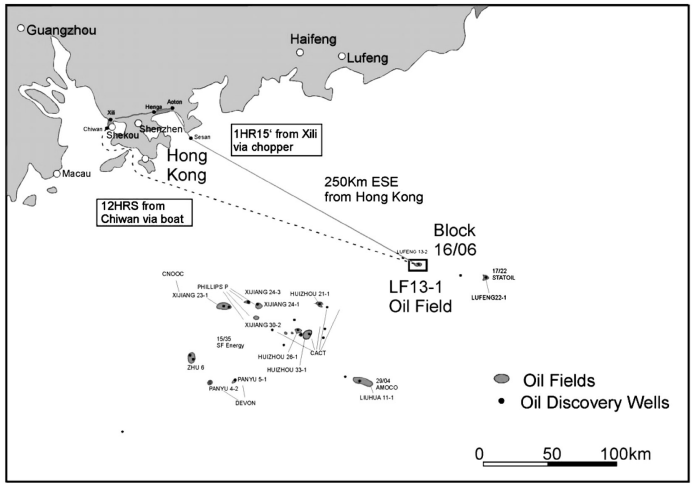

図 1 LF13-1 油田位置図

94\%と極めて高い状態に到達していることから,「生産 後期油田」と言える。しかしながら, 水平井の追加掘削 等によって, 現在も油の回収率を着実に増やしながら生 産を続けている油田である。

1993 年の第 1 次掘削キャンペーン以降，本油田では これまでに 7 回の掘削キャンペーンが実施され，合計 35 坑の開発井 (うちサイドトラック 8 坑) が掘削された。 第 1 次掘削キャンペーンでは傾斜井であったが, 第 2 次 掘削キャンペーン以降は水平井になった。1996 年には 本油田の生産ピークを迎え, 油の日産量は $25,000 \mathrm{bbl}$ 強 を超えた。その後の油生産量の減退を補うために, 1998 年 2004 年にかけて，第 3 次 5 次掘削キャンペーン が断続的に実施された。さらに回収率を上げるため，第 6 次 $(2004$ 年 11 月〜 2005 年 1 月）および第 7 次 $(2005$ 年 11 月〜 2006 年 9 月) 掘削キャンペーンが実施され, 「生 産後期油田」とはいえ，大幅に油を増産することができ た。2007 年 5 月末日時点の油の日産量は約 11,000 bbl 強
（合計 27 坑の生産井）である（図 2)。生産井 1 坑あた りの油の日産量は平均 $400 \mathrm{bbl}$ 程度である。生産開始か ら現在まで約 6,400 万 bbl の油が生産されており, 回収 率はすでに当初想定の 2 倍以上に到達している。

筆者らは, 上述の第 6 次および第 7 次掘削キャンペー ンにおいて, 地質・油層スタディ, 計画立案, 掘削オペレー ションおよびポストウェルスタディに携わった。本稿で はまず，生産後期の段階にある本油田開発の難しさ，ポ イント, 着眼点について述べる。そしてそれぞれのキャ ンペーン成果と比較検討結果について言及する。さらに 地質・油層の観点から, 増産によって得られた知見につ いてまとめる。また水平井掘削時の地質ナビゲーション 技術についても, LWD (logging while drilling) データな ぞを用いて簡単に紹介する。

\section{LF13-1 油田開発の難しさとキーポイント}

本油田は，第三系中新統珠海層（Zhuhai Formation） の $2500 \mathrm{~m}$ 砂岩油層（2500 m 層と略称）および $2370 \mathrm{~m}$ 砂 岩油層からなる。本稿では, 第 6 次および 7 次掘削キャ ンペーンの主要対象層である $2500 \mathrm{~m}$ 層の話題に絞る。 $2500 \mathrm{~m}$ 層は, 上位から下位に向けて 26 のサブレイヤー （SL-1 ～26）に区分される。 $2500 \mathrm{~m}$ 層のオリジナルの端 水面は単一であり, 初期の油コラムは $50 \mathrm{~m}$ あまりであ る。本層の貯留岩性状が不均質なこと, および既存開発 井位置が偏在することから, 油の生産に伴い, 端水面は 極めて不均一に上昇している。図 3 で示されるように, 現在構造縁辺部よりも構造中心部（特に開発井が位置 している周辺）がスウィープされ，端水面がより高いレ ベルまで上昇している現象が認められる。またスウェプ トゾーン下位の泥岩層直下のレイヤーにも, 油の取り残

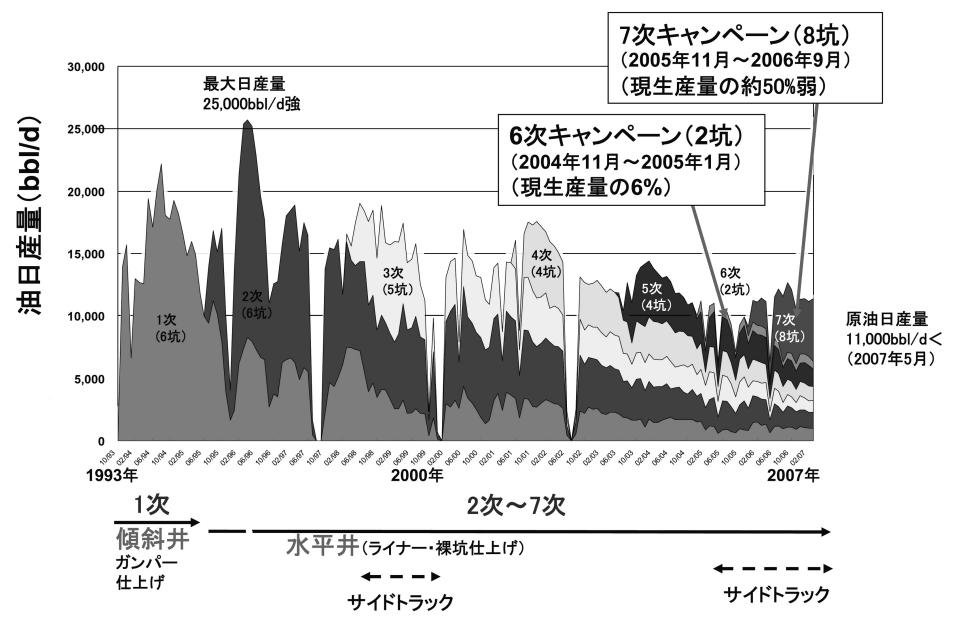

図 2 LF13-1 油田第 1 次〜 7 次掘削キャンペーンにおける油の日産量の変化 


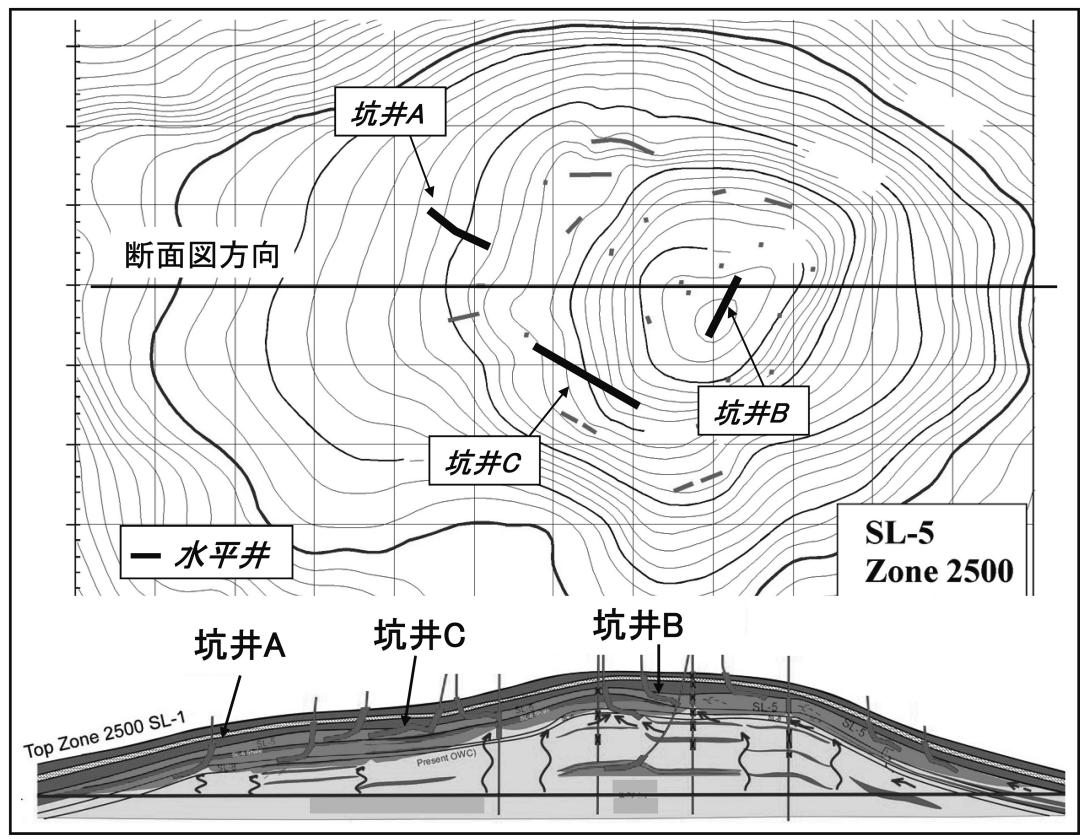

図 3 第 6 次・ 7 次掘削キャンペーンの代表的な水平井ロケーション図および模式断面図

しが存在する。本油田ではこれまでに 35 坑の生産井が 掘削されているが，本油層部における岩相の側方変化が 激しいことから，地質モデルや油層シミュレーションに よる油の残存領域やオイルコラムを正確に推定するのは 難しい。また，本油田はボトムウォータータイプの水 押しであることに加え，油層中部〜下部にダルシーオー ダーの高浸透性砂岩ゾーンが発達することから，油の生 産に伴い，生産井へのウォーターコーニングが起きやす い。以上の諸点から，本砂岩油層開発に際してのキーポ イントは，以下の 2 つが挙げられる。

(1) 水平井掘削後に急激な水含有量の上昇を起こさせ ず，長期間にわたり油の安定生産（高い油含有量） を維持させることのできる「砂岩油層のスウィート スポット」を，地質・油層工学の両観点から，いか に的確に推定するか。

(2) 推定されたスウィートスポット内において, 油の生 産に寄与する貯留層の水平掘削長を稼ぐために，い かにして地質情報を正確に水平井掘削ナビゲーショ ンに反映させるか。

(1)に関しては，これまでの地質・油層スタディから， 仕上げ層の貯留岩性状および同層直下の低浸透率ゾー ン（バリヤーあるいはフィルター）の存在がポイントの 1 つになることは，定性的ながら考えられていた。第 3 章および 4 章では, 第 6 次および 7 次掘削キャンペーン 成果の比較を交えて説明する。(2)については第 5 章で述
ベる。

3. 第 6 次および第 7 次掘削キャンペーンについて

\section{1 成果概要}

第 6 次および第 7 次掘削キャンペーンでは，それぞれ 2 坑(サイドトラック 1 坑含む) および 8 坑 (サイドトラッ ク 5 坑含む）の合計 10 坑の水平井が掘削された。第 6 次掘削キャンペーンでは, 当初本油田西部に発達が期待 される $2500 \mathrm{~m}$ 層最上部（サブレイヤー1〜 5) の高浸 透率砂岩が仕上げ対象層であった。しかし, 水平井に先 行して掘削されるパイロット坑によって, 同地域仕上げ

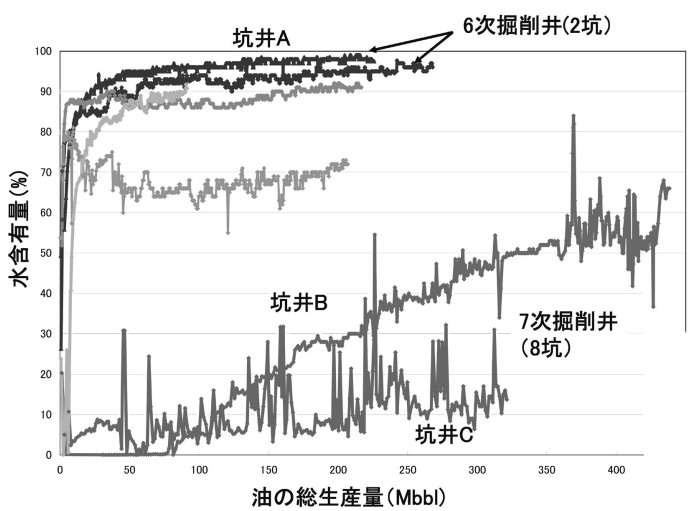

図 4 第 6 次・ 7 次掘削キャンペーン坑井の油総生 産量と水含有量変化図 


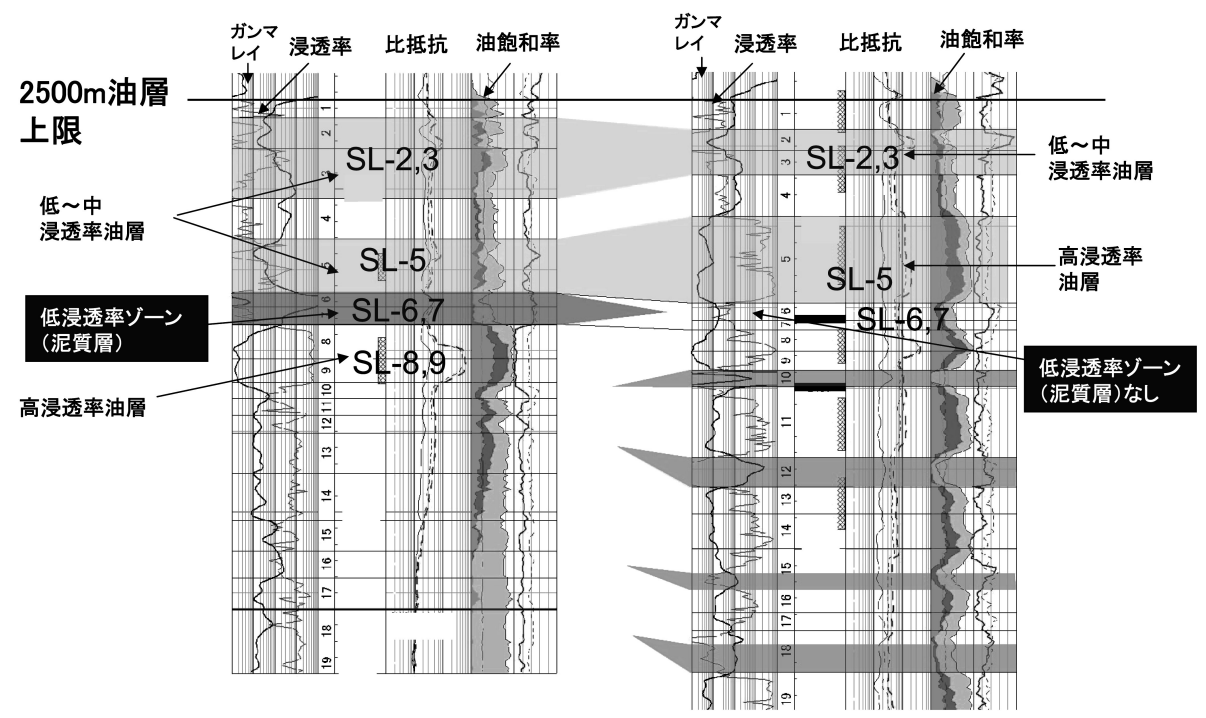

図 $52500 \mathrm{~m}$ 油層上部のサブレイヤー区分と岩相変化（例）

対象層部に良好な貯留岩性状を持つ油層の発達のないこ とが判明したため, 主要水平仕上げ層は, 2 坑ともサブ レイヤー8（ダルシーオーダーの高浸透率細粒〜中粒砂 岩油層) に変更された。掘削の結果，2坑井とも主にサ ブレイヤー8から油を産出した。しかしながら，生産開 始後から水含有量の急上昇が認められた（図 4)。この 結果, 2007 年 5 月の現時点において, 第 6 次キャンペ ーンの坑井から生産される油の日産量は, 油田全体生産 量（生産井は合計 27 坑）の約 $6 \%$ 程度に留まっている。

一方, 第 7 次掘削キャンペーンでは, $2500 \mathrm{~m}$ 層のサ ブレイヤー5（低〜中程度の浸透率を有する極細粒〜細 粒砂岩層）が主要仕上げ対象層となった。掘削の結果, ほぼ予定通りに仕上げられ, いずれの坑井も油を産出し た。本キャンペーンのロケーション選定に際しては，仕 上げ層の貯留岩性状評価スタディに加え，同層直下の低 浸透率ゾーン (バリヤーあるいはフィルター) の存在 (図 5）に着目した地質・油層スタディを実施した。特にサ ブレイヤー 5 直下の低浸透率ゾーン（サブレイヤー 6 , 7 の泥質層）の存在が重要と考え，同サブレイヤーの泥 質岩層厚マップ, 垂直浸透率マップ, ネットグロスマッ プ，残存飽和率マップなどを用いて，低浸透率ゾーンの 正確な分布, 介在状況の把握をこの地質・油層スタディ で試み，ロケーション選定に反映させた。その結果，同 キャンペーンでは, サブレイヤー 5 を仕上げたほとんど の坑井で, 急激な水含有量の上昇は認められなかった。 中でも 6 坑めに掘削された水平井（坑井C）は, 生産開 始約 9 か月後の 2007 年 5 月末日においても，本油田に おける 1 坑あたり平均日産油量の 3 倍以上のレートで安
定生産（水含有量は 10 ～15\%）を維持し，極めて良好 な生産井となっている。既存生産井からの生産量減退 が急速に進行する生産後期油田の中にあって, 2007 年 5 月末時点で, 第 7 次キャンペーンの坑井から生産され る油の日産量は, 油田全体生産量（生産井は合計 27 坑） の約 5 割弱を充当する成果となった（図 2)。

上述のように，いずれの掘削キャンペーンも成功裏に 終わつたが, 生産開始後の生産パフォーマンスにおいて は, 両キャンペーン間で大きな差が生じる結果となった (図 4)。この差が生じた主な要因として, 仕上げ対象層 自体の貯留岩性状と同時に, 仕上げ層直下の低浸透率 ゾーン（サブレイヤー 6,7 の泥質層）の存在（図 5）が, 大きく関与していることが改めて認識された。以下に, 両キャンペーンの地質状況および生産パフォーマンスの 差について, 各キャンペーンの代表井を用いて詳述する。

3.2 代表井の地質状況と生産パフォーマンス

(1) 第 6 次キャンペーン 坑井 A

図 6 は, 坑井 A の坑跡に沿う地質断面図である。坑 井 A の LWD 検層データおよび近隣坑井のワイヤーライ ン検層のガンマレイと浸透率のデータを一緒に示す。本 井は本油田構造の西翼部に新掘井として掘削された。本 井の水平仕上げ区間（サブレイヤー8）は, ダルシー オーダーの浸透率を有する高浸透率細粒〜中粒砂岩であ る。同仕上げ区間の上位のサブレイヤー 6,7 は泥質層 を挟む低浸透率極細粒〜細粒砂岩からなる。一方, 下位 のサブレイヤー 9 以深はほとんどが泥質層を挟まないダ ルシーオーダーの高浸透率細粒〜中粒砂岩である。本井 のパイロット坑および周辺の既存坑井デー夕解釈結果か 


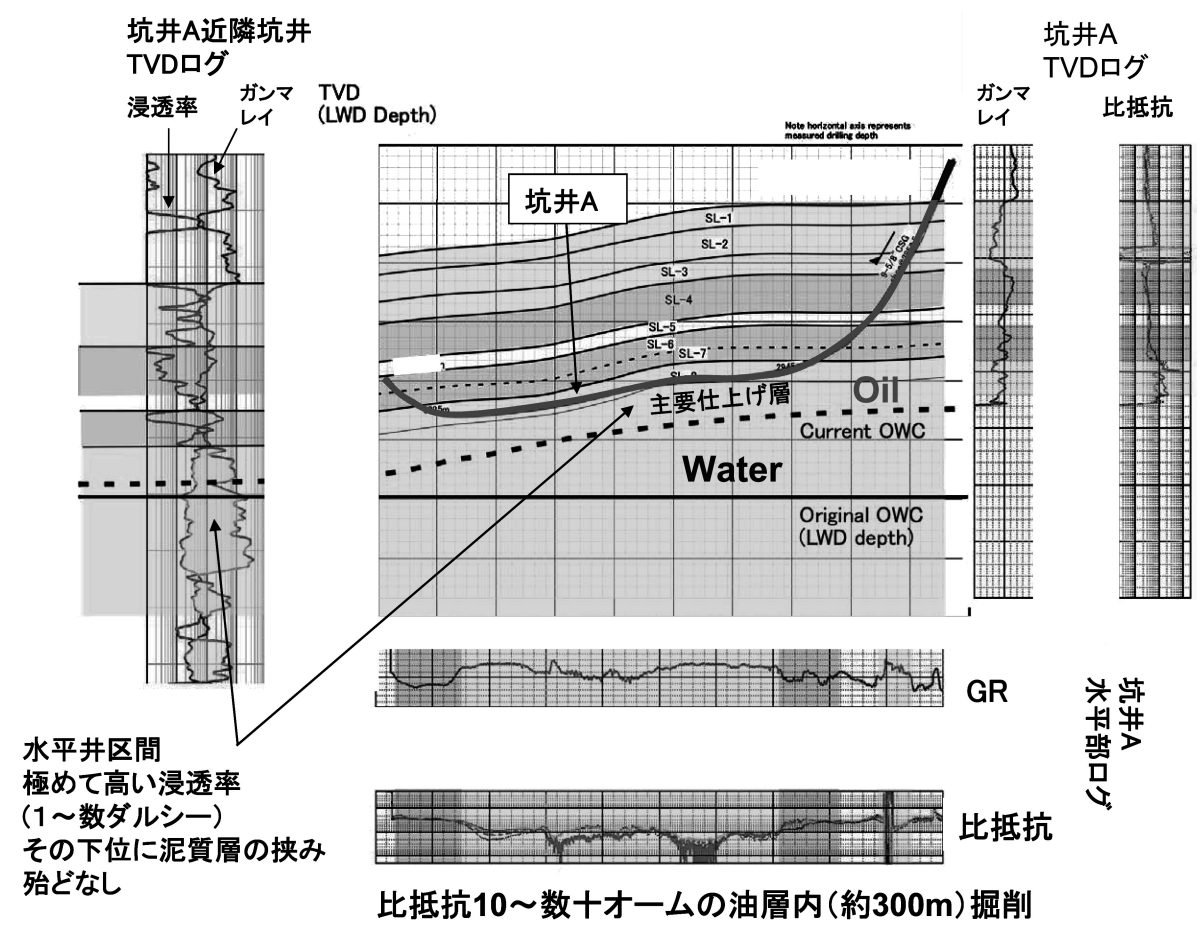

図 6 坑井 Aの坑跡に沿つた地質断面図

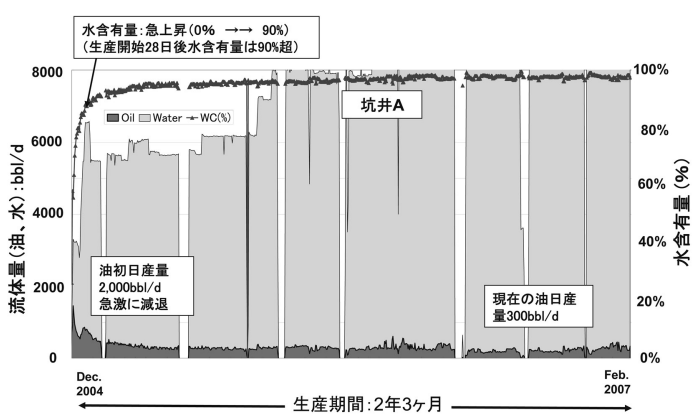

図 7 坑井 $\mathrm{A}$ における油の日産量, 水含有率の変化

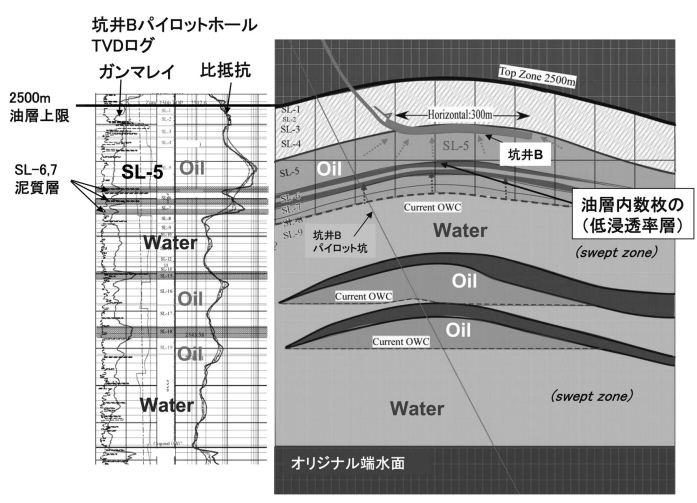

図 8 坑井 B の坑跡に沿つた地質断面図

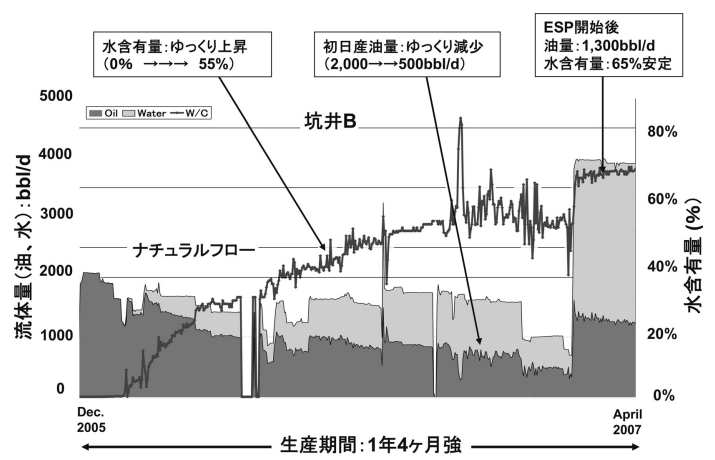

図 9 坑井 B における油の日産量, 水含有率の変化

ら, 本水平井掘削時の近隣の端水面は, 本水平井から数 $\mathrm{m}$ 程度下まで上昇していると解釈された。

図 7 は坑井 A の仕上げ後の生産パフォーマンスを示 している。横軸は生産開始からの時間, 縦軸は油の日産 量と水含有量である。本井の生産開始直後の水含有量は $0 \%$, 油の日産量は $2,000 \mathrm{bbl}$ 程度であった。しかしなが ら, 油の生産に伴い水含有量の急激な上昇が認められ, 約 1 か月後には水含有量は $90 \%$ 超え, 逆に油の日産 量は数百 bblに減退した。その後はおおむね安定し, 生 産開始してから 2 年 3 か月経過した時点では, 水含有量 は 96 ～98\%程度, 油の日産量は $200 〜 300 \mathrm{bbl}$ 程度を 維持している。なお本井は生産開始直後, 急激な水含有 


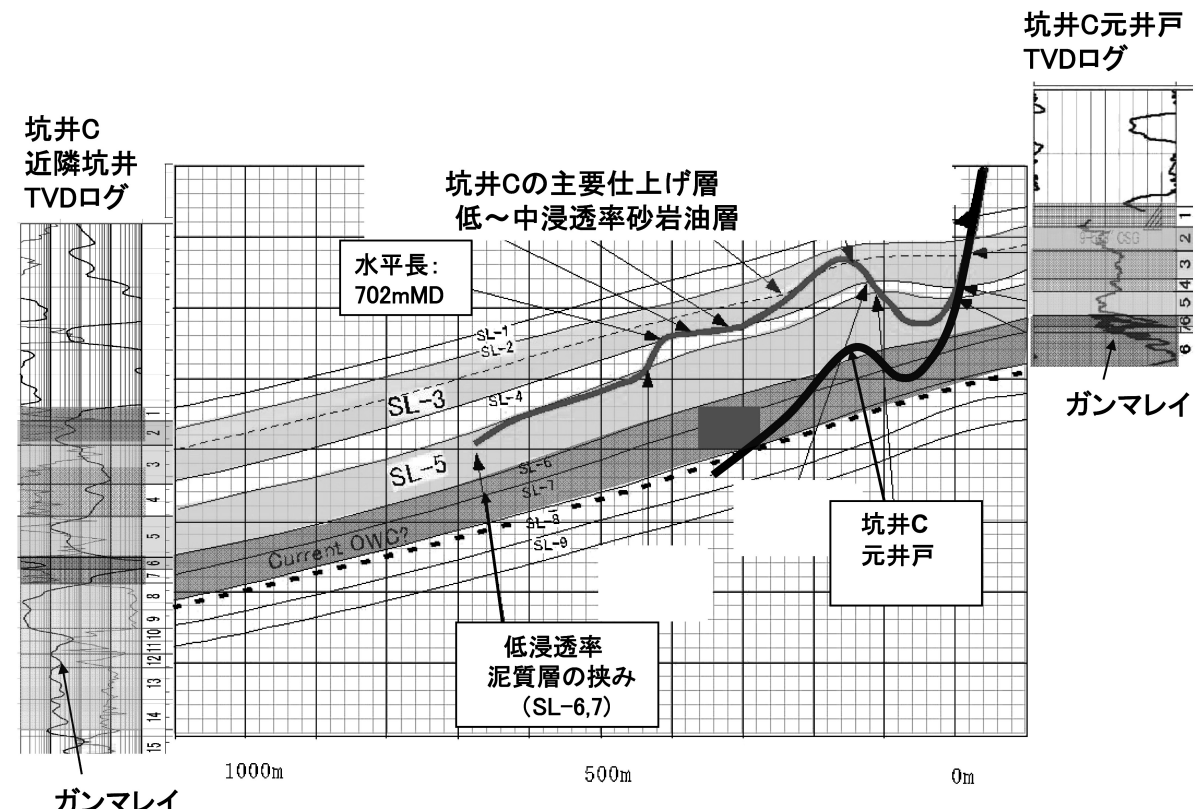

図 10 坑井 C の坑跡に沿つた地質断面図

量の上昇と油の減退が認められたことから，総流体量を 増やし油の生産量を維持していくため, ESP (electrical submersible pump）が使用された。

(2) 第 7 次キャンペーン 坑井 B

図 8 は, 坑井 B の坑跡に沿う地質断面図である。パ イロット坑の LWD 検層データも一緒に示す。本井は本 油田のほぼ構造頂部付近に新掘井として掘削された。本 井の水平仕上げ区間（サブレイヤー5） は，数百 md らダルシーオーダーの中〜高浸透率細粒〜中粒砂岩であ る。下位のサブレイヤー 6,7 は, 比較的薄い数枚の泥 質層（数十 $\mathrm{cm} \sim 1 \mathrm{~m}$ 弱）を挟む，低浸透率極細粒～細 粒砂岩からなる。さらに下位のサブレイヤー 8,9 など は泥質層をほとんど挟まないダルシーオーダーの高浸透 率細粒〜中粒砂岩からなる。本井のパイロット坑およ び周辺の既存坑井デー夕解釈結果から, 本井掘削時に は，近隣の端水面は本水平井から $11 \mathrm{~m}$ 程度下のサブレ イヤー 8 まで上昇していると解釈された。

図 9 は坑井 B の仕上げ後の生産パフォーマンスを示 している（軸は図 7 に同じ)。生産開始直後の水含有量 は $0 \%$, 油の日産量は $2,000 \mathrm{bbl}$ 程度であった。1.5 か月 程度，水含有量は $0 \%$ を維持し，油生産量も $1,500 \mathrm{bbl}$ 程度であった。その後も水含有率の上昇はゆっくりで あり, 油の安定生産が得られたことから, 自噴で生産 が続けられた。生産開始の 1 年 2 か月間で, 水含有量は $55 \%$ 程度までゆっくり上昇し，油の日産量も $500 \mathrm{bbl}$ ま でゆっくり減少した。その後, 油の増産を目的として

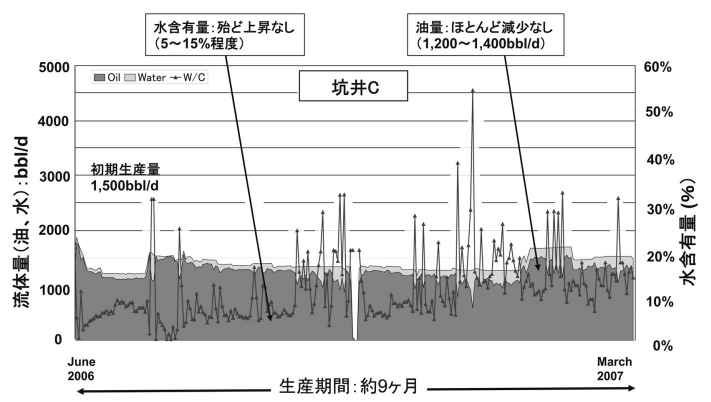

図 11 坑井 Cにおける油の日産量, 水含有率の変化

ESP を導入することとなった。ESP 開始後, 水含有量は 65\%程度に上昇したものの, その後は安定し, 油の日産 量は $1,000 \mathrm{bbl}$ 弱を維持しており, ESPによる流体の波 み上げ量増加後も, 急激な水含有量の上昇が認められな い。これは本井の特徵の 1 つに挙げられる。

(3) 第 7 次キャンペーン 坑井 C

図 10 は, 坑井 C の坑跡にほぼ沿う地質断面図である。 坑井 Cパイロット坑の LWD 検層データも一緒に示す。 本井は本油田構造の南西部において, 構造頂部から南西 翼部に掘削されたサイドトラック井である。本水平井は 100 〜数百ダルシー程度の低〜中浸透率極細粒〜細粒砂 岩からなるサブレイヤー $2,3,4,5$ に掘削された。下 位のサブレイヤー 6,7 は, 水平井のキックオフポイン 卜付近では, 比較的厚い $2 \mathrm{~m}$ 程度の泥質層を挟む低浸透 率極細粒〜細粒砂岩からなる。水平井の TD 付近に向け て, 泥質層は比較的薄くなる。さらに下位のサブレイ 
ヤー 8，9などは，泥質層をほとんど挟まないダルシー オーダーの高浸透率細粒〜中粒砂岩からなる。周辺の既 存坑井デー夕解釈結果から, 本井周辺の端水面は, サブ レイヤー 7 直下付近まで上昇していると解釈された。

図 11 は坑井 Cの仕上げ後の生産パフォーマンスを示 している（軸は図 7 に同じ)。本井の油層部は, 坑井 $\mathrm{A}$ や坑井 B に比較すると浸透率が低いことから, 油の生 産量を維持するため生産開始時から ESPが導入された。 本井の生産開始直後の水含有量は数\%, 油の日産量は $1,500 \mathrm{bbl}$ 程度であった。その後, 水含有量の上昇はなく, 生産開始後 9 か月間たつた時点でも, 水含有量は 5 15\%程度であり，油の日産量も 1,200〜 1,300 bbl を維持 している。構造頂部付近で $10 \mathrm{~m}$ 以上の油コラムが確認 された坑井 Bよりも, 生産パフォーマンスは良好であり, 第 7 次掘削キャンペーンで最も優秀な生産井となつた。

\section{3 代表井の地質状況と生産パフォーマンスの考察}

(1) 坑井 A

坑井 $\mathrm{A}$ の水平仕上げ区間およびその下位は，低浸透 率の泥質層をほとんど挟まないダルシーオーダーの高浸 透率砂岩層からなることから，生産開始直後から，仕上 げ区間のいずれかでウォーターコーニングが起きたと推 察される。顕著なウォーターコーニングを防ぐバリヤー の存在がないことによって，水含有量の急激な上昇を招 き, 相対的に油の日産量は急激に減退したと考えられる。

(2) 坑井 B

坑井 B の水平仕上げ区間直下の, サブレイヤー 6,7 に存在する数枚の低浸透率泥質層が, 生産開始後の顕 著なウォーターコーニングを和らげるフィルターの役割 を果たしていると推察される。それによって水含有量の 急激な上昇は起きず，油の日産量の急激な減退は起きな かつた。また，本水平井が構造頂部付近に掘削され，仕 上げ層が中〜高浸透率の砂岩層であったことが, 1 年 2 か月あまり ESPを使わず，油を安定生産できた一助に なっていると考えられる。

(3) 坑井 C

坑井 Cのキックオフポイント付近では，掘削上の制 限から水平坑位置が下がり, ウォーターコーニングのリ スクは否定できない状況にあった。しかしながら，同地 域に発達するサブレイヤー 6,7 の比較的連続性の良い 泥質層が, 生産開始後の顕著なウォーターコーニングを 防ぐバリヤーの役割を果たしていると考えられる。それ 以外の水平区間では，薄いながらも直下に発達するサブ レイヤー 6, 7 の泥質層が, ウォーターコーニングを和 らげるフィルターの役目をしていると推察される。また, 本水平井の仕上げ層が低〜中浸透率砂岩層であることが 顕著なウォーターコーニングを防ぎ，かつこのような油
層を水平坑で十分長い区間仕上げることによって，低浸 透率のハンディキャップが相殺され, 持続性の高い生産 パフォーマンスを維持できる要因となっているものと考 えられる。

\section{4 油層シミュレーションによる検証}

図 12 は, 第 7 次掘削キャンペーン後, その結果によ り修正された油層シミュレーションモデルに基づいて推 定された, $2500 \mathrm{~m}$ 層の砂岩率断面図と油飽和率（数年 単位の年次展開）である。 $2500 \mathrm{~m}$ 層の中部〜下部油層 で既存生産井が位置する地域を中心に, 顕著な油飽和率 の減少, つまりウォーターコーニングの進行が認められ る。しかしながら, サブレイヤー 6, 7 の泥質層を含む その上位層（サブレイヤー 1 ～5） では, 幾つかの坑井 で仕上げられているにもかかわらず，油飽和率の減少は 相対的に進行が遅い。これは, サブレイヤー $1 \sim 5$ の浸 透性が相対的に低いことに加え, サブレイヤー 6, 7 が 少なからず急激なウォーターコーニングの進行を防ぐバ リヤー（和らげるフィルター）となっていることが見て 取れる。

\section{4. 地質・油層工学的見地に基づく考察のまとめ}

(1) 第 6 次および第 7 次掘削キャンペーンの掘削結 果から, 坑井は以下の 3 つのタイプに区分される（図 13)。

タイプ1 (坑井 A) : 急激な水含有量の上昇, 急激な 油量の減少

タイプ 2 (坑井 B) : ゆっくり水含有量上昇, ゆっく り油量減少

タイプ 3 (坑井 C) : 極めてゆっくり水含有量上昇, 極 めてゆっくり油量減少

（2）水平井の場合，生産パフォーマンスを大きくコン トロールする要因の 1 つとして, 仕上げ層直下の低浸透 率ゾーン（泥質層）の存在がある。水平井直下の低浸 透率ゾーンが，時にはウォーターコーニングを和らげる フィルターとなり，時にはそれを防ぐバリヤーの役目を 果たしていると考えられる。本油田の $2500 \mathrm{~m}$ 層のサブ レイヤー 6,7 の低浸透率ゾーンは, その役目を担って いる例の 1 つである。

（3）生産パフォーマンスを大きくコントロールするも う 1 つの要因として, 仕上げ層の貯留岩性状が挙げられ る。水平坑がダルシーオーダーの高浸透率砂岩層であれ ば, よりウォーターコーニングが起きやすく, 低〜中程 度の浸透率砂岩層であれば，それを遅らせることができ る。ただし, 低浸透率砂岩層の場合, 水平坑でより長い 区間を仕上げる必要がある。

（4）仕上げ層が高浸透率砂岩からなり, その直下に低 

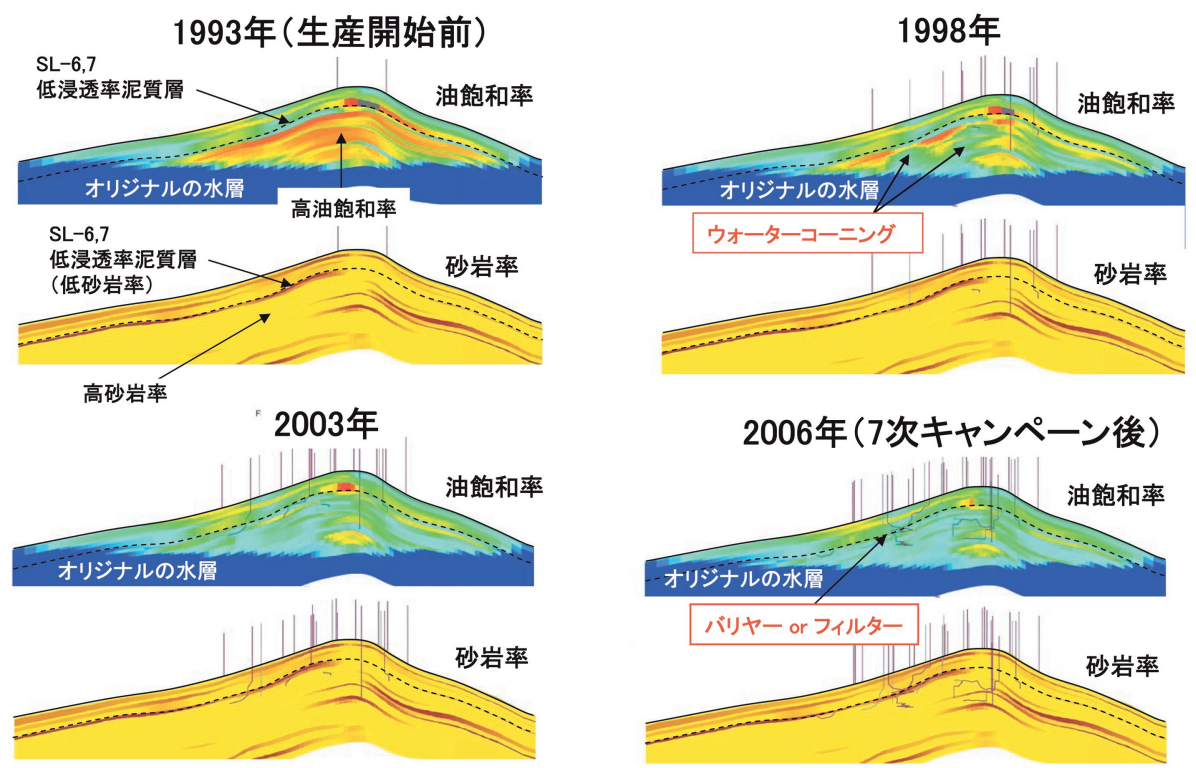

図 $122500 \mathrm{~m}$ 層の砂岩率断面図と油飽和率（数年単位の年次展開）

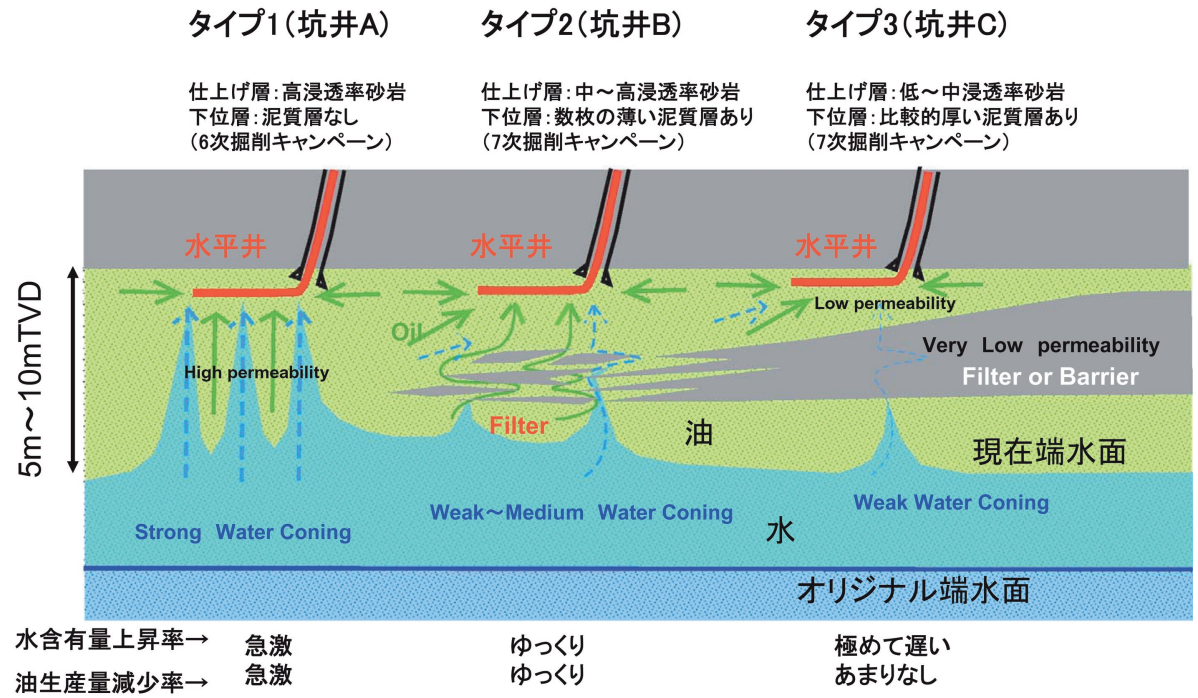

図 13 3つの坑井タイプによる地質状況と生産パフォーマンスの差（説明概念図）

浸透率ゾーンがほとんどない〜全く発達していない地 域では，坑井 A に代表されるようなタイプ1の生産パ フォーマンスを示す。仕上げ層が高浸透率砂岩であって も, 直下に比較的薄い低浸透率ゾーンが数枚存在する地 域では，おそらく泥質層は断続的に発達していることか ら, フィルターとして機能するであろう。その結果, 坑 井 B に代表されるようなタイプ 2 の生産パフォーマン スを示す。仕上げ層が低〜中程度の浸透率砂岩であり, 少なくとも直下に低浸透率ゾーンが存在する地域では, おそらく泥質層はフィルターあるいはバリヤーとして機
能するであろう。その結果, 坑井 Cに代表されるよう なタイプ 3 の生産パフォーマンスを示す。

5. 水平掘りの地質ナビゲーション

本油田では, 地質・油層スタディに基づいて計画さ れたロケーションにおいて, 油の生産に寄与する油層の 掘削長をいかに稼ぐことができるかが, もう 1 つの重要 なポイントである。ここでは, 油の生産に寄与する貯留 層の水平掘削長を稼ぐために, 地質情報を正確に水平井 掘削ナビゲーションに反映させる技術について簡単に述 


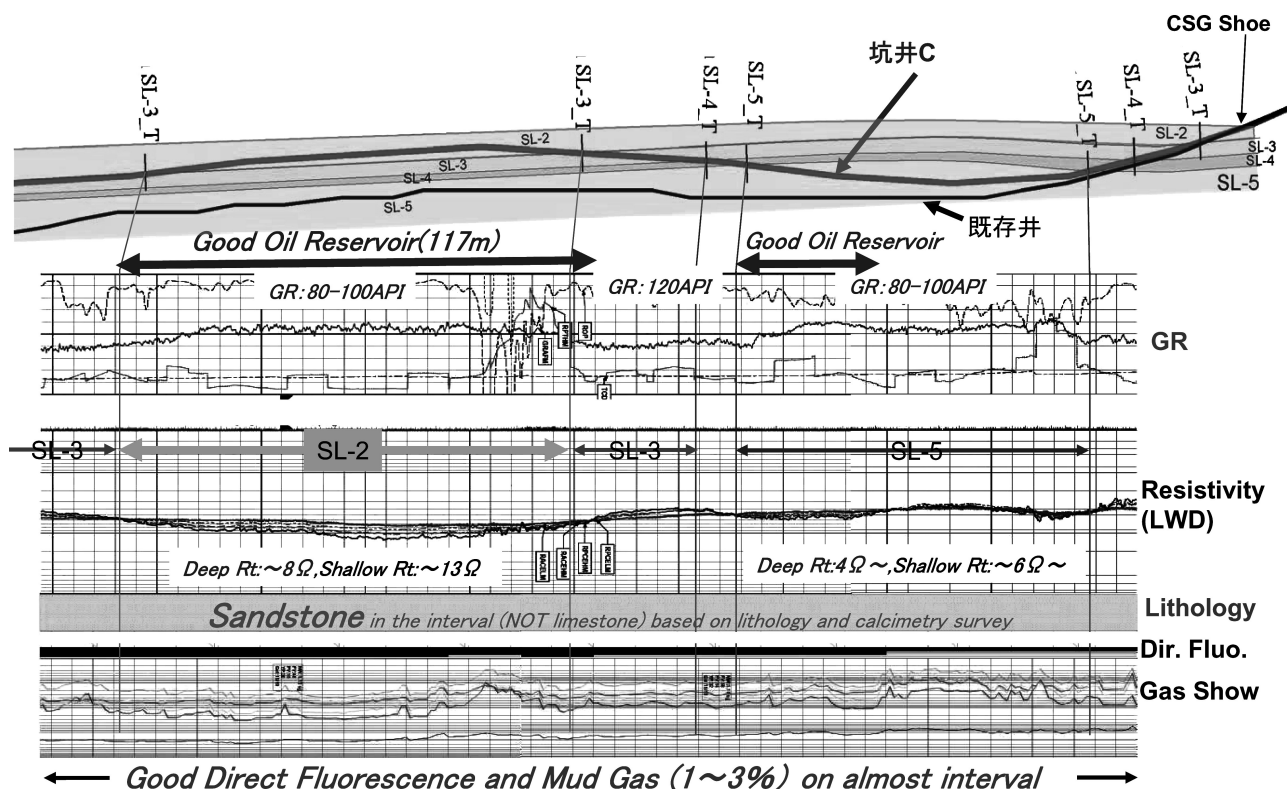

図 14 坑井Cのコンポジットログ

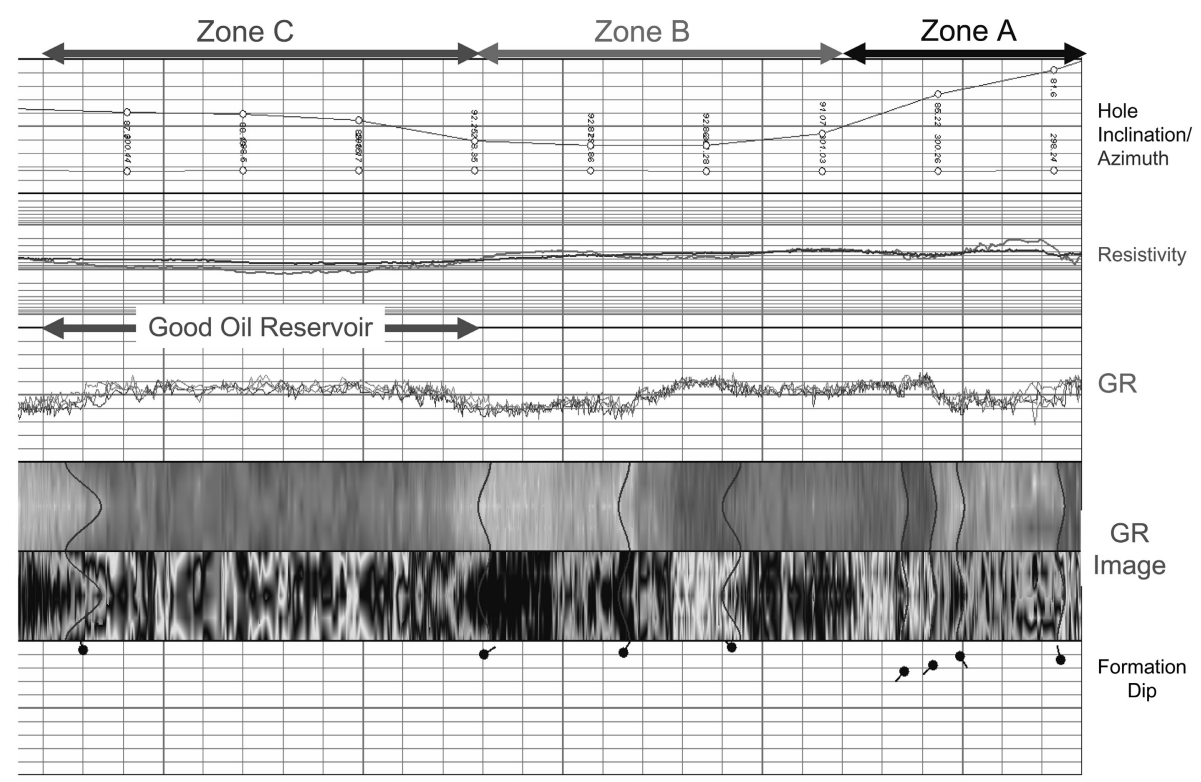

図 15 坑井 Cのリアルタイム・ログ（地層イメージ含む）

ベる。

当該掘削キャンペーンにおいては，スライド掘進 (ド リルストリングを回転させず，ダウンホールモーター の駆動力で掘進する方法 ) を行わずに坑跡コントロール が可能な, ロータリーステアラブルツール (RST), お よび LWD ツールス（いずれも Baker Hughes Inteq 社製） を使用し、リアルタイムで各種データを監視しながら
適宜坑跡をコントロールして, 坑井のナビゲーションを 行った。RSTを用いることの長所は, ビットにベント 角を付ける必要がないため, 非常に安定した坑内状況が 実現可能であり, 大偏距水平坑掘削のリスクが低減され ること, また, LWD ツールスが常に回転しているため, 方位指向性を持ったデー夕も欠損なく連続的に取得可能 なことである。特に後者については, ガンマ線検層を用 
いた地層イメージの取得が可能であり, 地層傾斜等の情 報もリアルタイムで取得可能なことから，坑井ナビゲー ションを行うにあたって強力なサポートツールとなる。

図 10 に例示した坑井 C は, 裸坑でサブレイヤー 5 を仕上げていた既存井の 8-1/2"坑をプラグバックし, 9-5/8” CSG シューから新規のマルチターゲット（サブレ イヤー1〜 3 と5）へ向け, サイドトラックを行ったも のである。新規ターゲットの一部は既存井の上位に位 置するため, サイドトラック開始直後のビルドアップ掘 進作業にあたつては，できる限り速やかに坑跡を上方へ と向け，下位から上位の地層へ向かって，サブレイヤー 境界のマーカーを認定しながらナビゲーションを行う必 要がある。図 14 はこの区間を拡大したものである。坑 井 Cの例では, リアルタイムデータを駆使しつつ坑跡 をコントロールし， $117 \mathrm{~m}$ にわたつて良好な油層（サブ レイヤー2）をとらえることができた。また，図 15 は， この区間の地層イメージを含むリアルタイムログであ る。Zone A はサイドトラック開始直後のビルドアップ 区間 (坑芯傾斜 $90^{\circ}$ 未満)，Zone B は油層をとらえるべ く上方へ向かって掘進している区間（坑芯傾斜 $90^{\circ}$ 以 上), Zone C は油層をとらえ, 傾斜を元へ戻しつつ油層 内を掘進し続けた区間である。地層イメージを見ると， マーカー境界が Zone A では上に凸，Zone B では下に凸， Zone C では再び上へ凸となる様子が明瞭に認められる。

LF13-1 油田はすでに生産後期を迎え，ターゲットと なる油層は従来に比べ格段に開発の難易度が増してい る。例えば，サブレイヤー 1 〜 3 とつた新規開発層は おしなべて層厚が薄い（数 $\mathrm{m}$ オーダー)。また, サブレ イヤー 5 のような比較的厚い油層であっても, 早期の ウォーターコーニングを避けるべく，できる限り油層の 最上部に坑井を配置する必要がある。このような条件下 での坑井ナビゲーションは，わずかな地質状況の変化で あっても，坑井コントロールに与える影響は非常に大き くなり，対処に苦慮することが多い。しかしながら，上 述のように最新のツールスによって得られる詳細な地質 情報を基に，以後の地質状況を素早く予測し，目的の油 層をとらえるべく繊細かつ大胆に坑芯方位・傾斜の調整 を行うのが，まさに開発後期油田における水平井掘削の 地質ナビゲーションの醍醐味と言えよう。

\section{6. 最 後 に}

LF13-1 油田は, 生産開始から 13 年余りがたち, 既 存生産井からの生産量減退は進行し, 平均水含有量は 94\% と極めて高い生産後期にある。このような状況の中, 特に第 7 次キャンペーンの坑井から生産される油の日産 量は, 油田全体生産量の約 5 割弱を充当するという, 大 幅な増産成果を上げることができた。本キャンペーンの 一連の作業に携わることのできた石油技術者の一員とし て，この上ない経験を得ることができた。地質・油層評 価スタディにおいては, 油の生産性（水含有量）をコン トロールする大きな要因の 1 つと考える油層内の低浸透 率ゾーンの発達に改めて着目し, 油田全域でスタディを 実施した結果，その重要性が実証された。また，水平井 を正確に地質ナビゲーションするための技術進歩は, 油 の増産への大きな貢献であったと言えよう。また地質・ 油層スタディや水平井掘削時, それらに従事した現場や 事務所の技術エンジニア同士の密なコミュニケーション が，本キャンペーンで増産成果を挙げることができた大 きな要因の 1 つであることは言うまでもない。

\section{謝 辞}

本稿の公表を許可された新南海石油(株)新華南石油開 発(侏)日鉱珠江口石油開発(怢および CCLS (CNOOC China Limited-Shenzhen）に深く感謝の意を表す。JHN 石油作 業公司の猪岡春喜氏には, 本稿作成にあたり, 便宜を図つ ていただき感謝する。石油資源開発侏福本暁氏および鳥 越隆弘氏, 新華南石油開発侏土井学氏, 日鉱珠江口石油 開発侏塩澤有史氏および藤原勝憲氏には，本稿に目を通 し有益な意見をいただき，心から感謝する。また 2 名の 査読者から有益なコメントをいただき，本文は改善され た。心よりお礼申し上げる。

\section{SI 単位換算係数}

\begin{tabular}{ll}
$\mathrm{bbl} \times 1.589874$ & $\mathrm{E}-01=\mathrm{m}^{3}$ \\
inch $\times 2.54^{*}$ & $\mathrm{E}-02=\mathrm{m}$ \\
darcy $\times 9.86923$ & $\mathrm{E}-13=\mathrm{m}^{2}$ \\
$\mathrm{md} \times 9.86923$ & $\mathrm{E}-16=\mathrm{m}^{2}$ \\
\hline *は正確な值 &
\end{tabular}

